\title{
Mechanical Properties Investigation of Multi-Lap Stainless Steel Sheets
}

\author{
Qasim M. Doos Al-Attaby ${ }^{1} \&$ Shaymaa Abdul Khader Al-Jumaili ${ }^{1}$ \\ ${ }^{1}$ Baghdad University, College of Engineering, Mechanical Engineering Dept., Baghdad, Iraq \\ Correspondence: Shaymaa Abdul Khader Al-Jumaili, Baghdad University, College of Engineering, Mechanical \\ Engineering Dept., Baghdad, Iraq. E-mail: sh.iraq79@yahoo.com
}

Received: June 26, 2015 Accepted: July 28, 2015 Online Published: August 18, 2015

doi:10.5539/jmsr.v4n4p34 URL: http://dx.doi.org/10.5539/jmsr.v4n4p34

\begin{abstract}
The mechanical testing and microstructers for austenititc stainless steel have been carried out to indicate the effect of the localized heating on the spot welds. The results indicated that the increasing of the heating will increase the tensile shear strength rapidly up to the expulsion point. Therefore, the hardness increases with the increasing of the weld nugget area. Hence, the fracturing tendencies have been observed inside the nugget. Nevertheless, the outer surface cracking is developed by adding a thin layer of pure metals between the two stainless steel 304L sheets. It was shown that the addition of pure metals, 3-lap sheets decreases the joint strength as compared with the 2-lap joints for the same parameters. The effect of micro cracking and the intensive brittleness decreases the joint strength. The excessive cracking was observed in 3-lap as compared with the 2-lap joint.
\end{abstract}

Keywords: austenititc stainless steel, joint strength, lap joint, resistance spot welding, stainless steel, solidification cracking

\section{Introduction}

Resistance welding (RW) is a fusion-welding process that uses a combination of heat and pressure to produce a localized heating what called nugget weld area, see Figure 1. The heat being generated by electrical resistance to current flow at the bulk workpieces and at the interfaces due to electrical resistance (Wei \& Wu, 2012) (Groover, 2007). Resistance spot welding is effective way to join metal sheets in various manufacturing, automobile, aerospace and packaging industries (M. Vural, 2004; Aslanlar, 2006; Cullen, Athi, Al-Jader, Shaw, \& Al-Shamma'A, 2007; Mukhopadhyay, Bhattacharya, \& Ray, 2009; Ambroziak \& Korzeniowski, 2010; Wei \& $\mathrm{Wu}, 2012)$. A typical car body contains thousands of spot welds for joining the mixture types of metal material and thickness of sheet (Welding, Industry, \& Practice, 2002; Vural, Akkuş, \& Eryürek, 2006). Hence, the process is used extensively for joining low carbon steel, stainless steels and galvanized steel components due to their wide applications as combined with the required properties(Agashe \& Zhang, 2003; Pouranvari, Abedi, Marashi, \& Goodarzi, 2008; Marashi, Pouranvari, Amirabdollahian, Abedi, \& Goodarzi, 2008; A. M. Al-Mukhtar \& Doos, 2013). In addition, aluminum alloys are more frequently used also in automotive industry especially as an alternative material for car-bodies with high impact strength and the weight ratio (Ambroziak \& Korzeniowski, 2010; Han, Thornton, Boomer, \& Shergold, 2010). Nevertheless, dissimilar materials are also welded. The amount of heat in the joint is determined by the material thickness and type, amount of the current and cross-sectional area of the welding tips and contact surfaces.

Resistance spot welding, like any process, affected by several factor such as; electrode force, electrode geometry, work piece and/or electrode misalignment, electrode surface roughness, electrode wear, temperature of electrodes and work piece, micro-movement at any of the surfaces (Welding et al., 2002), current flow, resistance of the circuit, and length of time the current is applied (Groover, 2007). Nevertheless, the main factors having an effect represent by; current, time, and electrode force (Groover, 2007; Aslanlar, Ogur, Ozsarac, Ilhan, \& Demir, 2007). The welding current, electrode pressure and hold time affected the thermo mechanical interactions of the welding process and changed the final nugget geometry volume, see Figure 1 (Tsai, Jammal, Papritan, \& Dickinson, 1992). The cracking and insufficient depth is the reason of the most toughness reduction (A. Al-Mukhtar \& Doos, 2013). The properties of most importance which influence weldability have been investigated. Therefore, the selection of suitable welding conditions, the fusion zone characteristics, and heat affected zone, HAZ play a significant role in 
any spot weldability investigations. The current study provoked the heat generation and resistance effect by inserting a high thermal sheet metal. Hence, the strength and fracturing were observed.

\section{Experimental Work}

\subsection{Material}

Welding was performed on a specimen prepared per the AWS standard, while changing the welding current and welding force in cycles of welding time (A. M. Al-Mukhtar, 2002; Kim, Lee, Lee, \& Rhee, 2004). In this study, we choose AISI $304 \mathrm{~L}$ type of austenitic stainless steel with thickness $0.8 \mathrm{~mm}$ was welded. For several years ago, austenitic stainless steel 304L have been employed in industrial applications such as pipes and pressure vessels for structural purposes. The influences austenitic stainless steel 304L on the industry are mainly due to its mechanical strength as well as excellent corrosion (Park et al., 2004; N R Anand1, 2013). The chemical composition and the mechanical properties are given in Table 1and Table 2, respectively (MatWeb, n.d.).

Table 1. Chemical composition of stainless steel

\begin{tabular}{|c|c|c|c|c|c|c|c|c|c|c|c|}
\hline \multirow{2}{*}{$\begin{array}{c}\text { Austenitic Stainless Steel } \\
\text { 304L }\end{array}$} & $\mathrm{C}$ & $\mathrm{Cr}$ & $\mathrm{Ni}$ & $\mathrm{Mn}$ & $\mathrm{V}$ & Мo & $\mathrm{Si}$ & $\mathrm{Ti}$ & $\mathrm{Nb}$ & $\mathrm{Cu}$ & S \\
\hline & 0.016 & 17.8 & 8.10 & 1.0 & 0.101 & 0.02 & 0.466 & 0.008 & 0.008 & 0.062 & 0.012 \\
\hline
\end{tabular}

Table 2: Mechanical properties of stainless steel

\begin{tabular}{lcccc}
\hline \multirow{2}{*}{ Austenitic Stainless Steel 304L } & $\sigma y(\mathrm{MPa})$ & Tensile strength $\sigma \mathrm{u}(\mathrm{MPa})$ & Elongation EL\% & HV. Vickers \\
\cline { 2 - 5 } & 241 & 586 & 44 & 161 \\
\hline
\end{tabular}

\subsection{Geometry and Specimen Preparation}

The geometry of specimen is rectangular with dimension based on American National Standards Institute (ANSI) and American Welding Society (AWS) (Connor, 1987; Zhou, Hu, \& Zhang, 1999; A. M. Al-Mukhtar, 2003). The dimensions for each plate to be spot welded are $78 \mathrm{~mm}$ length, $19 \mathrm{~mm}$ width, and overlap is $19 \mathrm{~mm}$, see Figure 1 . After cutting the specimens, it is necessary to their surfaces were chemically cleaned by acetone before resistance spot welding to eliminate surface contamination (Kahraman, 2007). The lap tensil shear specimen widly used as systematic testing for investigation joint strength, failure mode, microstructres and welding defects, see Refs (Vural et al., 2006; Shamsul, Hisyam, \& Muhibbah, 2007; Triyono, Purwaningrum, \& Chamid, 2013). The inserting a sheet in the middle of lap specimens was used in some case, but for the same metals, see Sin, Yang, Yu, Kim, and Kang (2007). Therefore, this work aims to show the effect of thermal and physical properties of different metals on the mechanical properties of the spot join. Thin layers of pure copper and pure aluminium with $0.09 \mathrm{~mm}$ and $0.1 \mathrm{~mm}$ thickness, respectively, were used as a transition material between the two sheets of austenitic stainless steel 304L, to investigate the joint strength, see Figure 1 (right). Three sets of samples were welded by fixing electrode force, welding time and using three values of the welding current has been changed sequentially for 4000, 6000 and 8000 Amp, by increasing 2000 Amp, respectively.
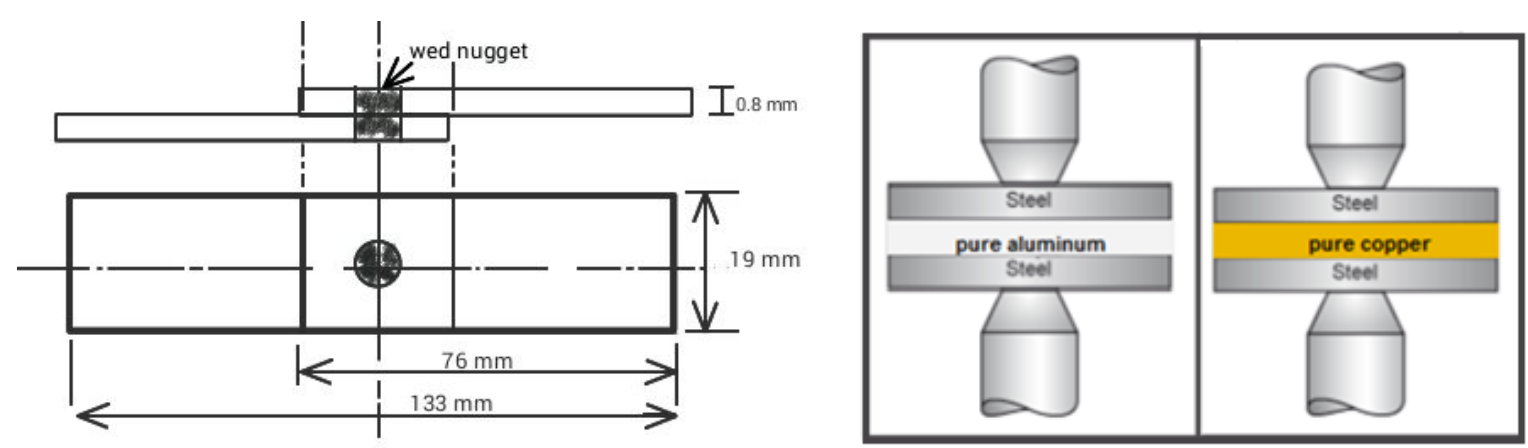

Figure 1. Dimension of tensile shear test (mm), ANSI/AWS standard 


\subsection{Materials Test}

Static strength was measured using the conventional tensile shear lap specimens that shown in Figure 1 (left) according to AWS practice (Zhou et al., 1999). All welds were tested in tensile shear using LARYEE computer control electronic universal testing machine. It was equips with high precision servo motor control system. Control system is full closed loop measuring and control system. Control software can automatically figure out routine data, such as load-extension and stress-strain curves. The available function of the machine is to maintain both the peak load and the weld strength. The lap shear specimen of two flat plates of $0.8 \mathrm{~mm}$ thickness with an overlapping distance of $19 \mathrm{~mm}$ was welded, see Figure1 (left). The geometry was approximated as closely as possible to pure shear made on the joint (A. M. Q. D. Al-Mukhtar \& Doos, 2013). The microhardness of cross section weld nugget was tested. The hardness measurements were carried out using a Digital Hardness Vickers Tester TH714 machine. Three hardness measurements were made and then take the average of them.

\section{Results and Discussion}

\subsection{Effect of Current on Joint Strength and Weld Nugget Area}

Welding current is the most parameter among all the parameters affecting the amount of heat obtained. According to Joule law, $Q=I^{2} R t$; where $Q$ is generated heat, $I$ is current, $R$ is electrical resistance of the circuit, and $t$ is time that the current is allowed to flow through the circuit (Zhang \& Senkara, 2006; Nodeh, Serajzadeh, \& Kokabi, 2008; Mirsalehi \& Kokabi, 2010). So when the weld current increases the joint strength (maximum load) increases due to the weld nugget area increasing until the maximum current value that achieved by the welding machine. The nugget size increasing until expulsion occurs. The results agree with different studies, see Ref (Aslanlar et al., 2007; Pereira, Ferreira, Loureiro, Costa, \& Bártolo, 2010; Moshayedi \& Sattari-Far, 2012). The increasing current, i.e. increasing the heat input will increase the melting area, see Figure 2. This usually leads to increase the strength of the joint. However, the increasing beyond the maximum ranges causing the splashing and expulsion of metal due to the complicated mechanism between the electrode force and nugget growing pressure between the sheets, see A. Al-Mukhtar and Doos (2013). Moreover, the continuing increased welding currents will cause the nugget diameter to become shorter as the result of the splashing in the interlayer (Shamsul et al., 2007).
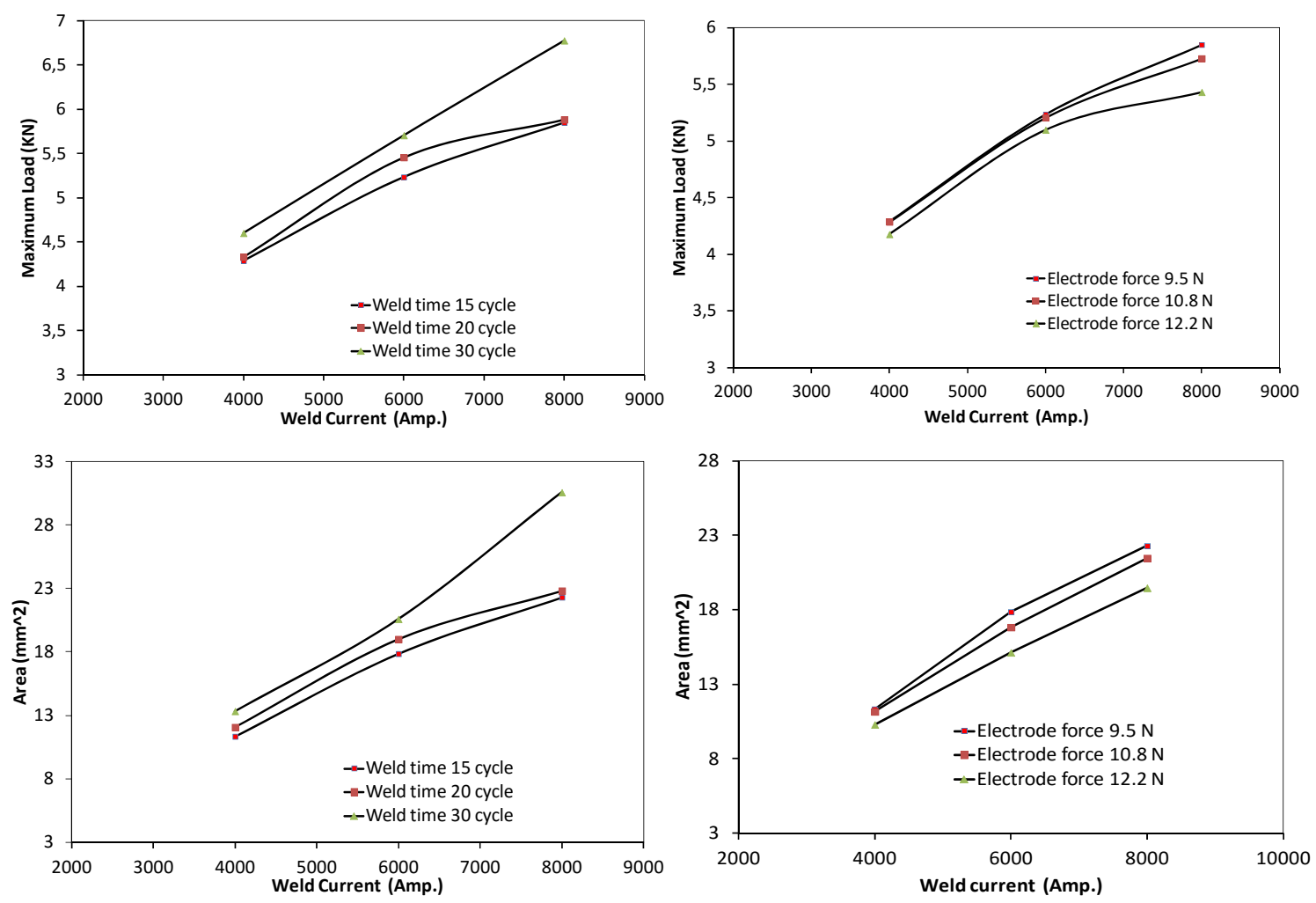

Figure 2. Effect of welding current on the tensile shear strength and weld nugget area 
That is agrees with almost works (Shamsul et al., 2007; A. M. Al-Mukhtar \& Doos, 2013). The weld area increase rapidly with weld current, from low current levels until expulsion occurs at the higher levels. A similar behaviour occurs with the weld strength, due to the direct relation between the weld area and its strength. Effect of welding current on the tensile shear strength and weld nugget area was shown in Figure 2.

The maximum load was obtained before the failure. The expulsion occurs at that maximum current. Hence, the cracking is initiated around the weld nugget. Subsequently, a pull out fracture will be developed.

\subsection{Effect of Weld Time on Joint Strength and Weld Area}

In the light of results obtained from the experimental work indicated that increasing weld time causes to enhance high heat input to weld zone, hence, increase weld nugget area (Nodeh et al., 2008). So the tensile-shear strength of joints will be increased. The effect of weld time less than the effect of weld current. The relations of weld time with joint strength and weld nugget area show in the Figure 3.
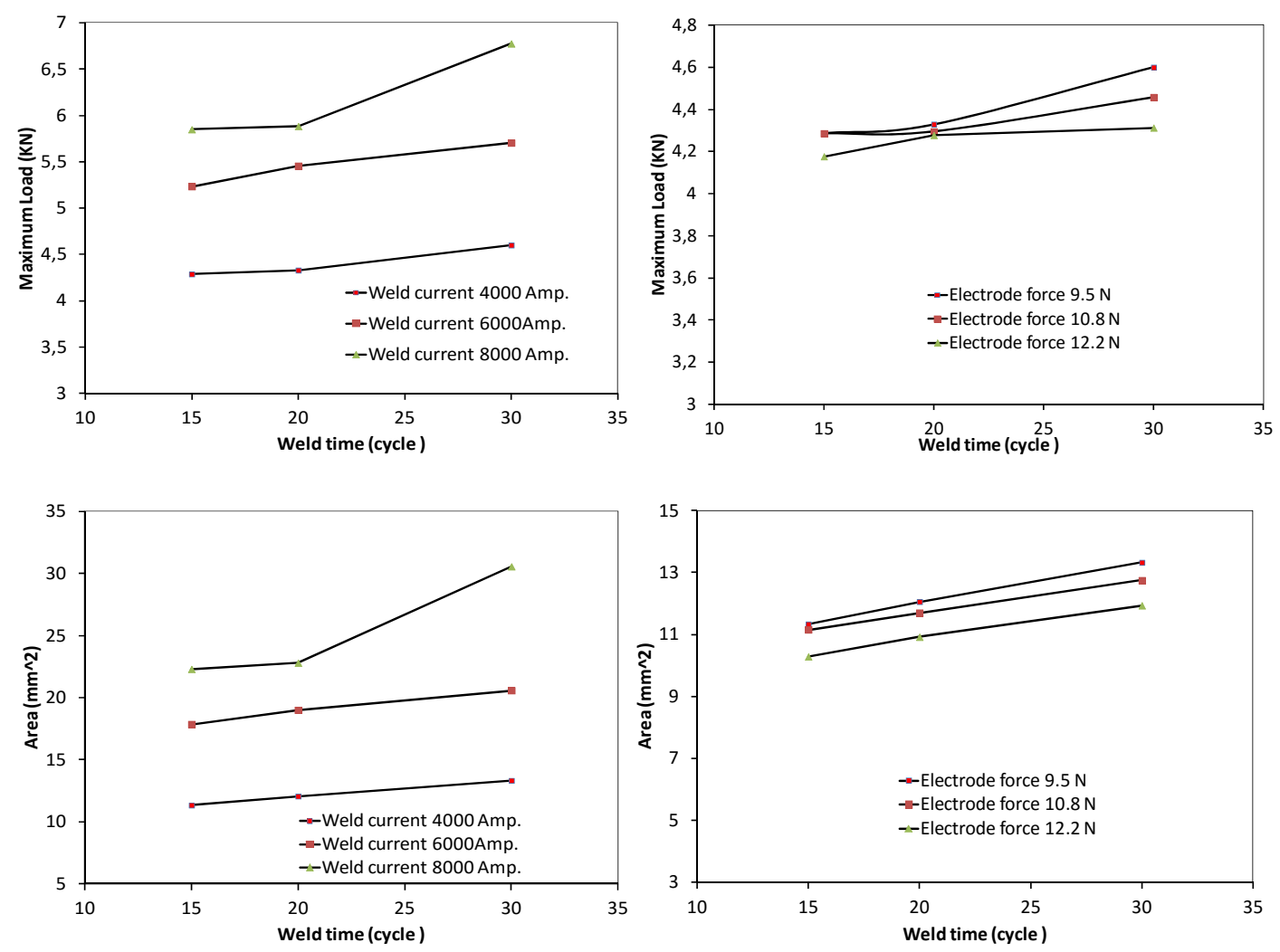

Figure 3. Effect of welding time on the tensile shear strength and weld nugget area

\subsection{Effect of Electrode Force on Joint Strength and Weld Area}

The effect of electrode force on joint strength and weld nugget area is investigated. Results showed that the increasing electrode force decreases fusion zone size and therefore leads to reduce weld nugget area and joint strength. The reason for the adverse effect of electrode force due to decreases the electric resistance and thus reduces the generated heat at the sheet-sheet interface. Effect of electrode force on the joint strength and weld nugget area were shown in Figure 4.

\subsection{Hardness Profile}

Microhardness for 2-lap and 3-lapspecimens has been measured. Generally the values of hardness distribution include the maximum values in HAZ. The less values were observed in fusion zone (weld nugget). HAZ and the weld zone hardness are mainly higher that the base metal hardness (Mukhopadhyay et al., 2009). The observed hardness profiles are similar to the ones reported by (Park et al., 2004; Aslanlar, 2006). The microhardness of as-welded specimen has values a little higher than the microhardness of transition pure copper specimen. The microhardness of specimen using pure aluminum as transition material has the highest values due to formation of 
intermetallic components under the same welding conditions. The reason of increase the microhardness of the specimen AL-ASS returns to formation solid compounds such as oxide aluminum. The microhardness distribution is shown in Figure 5.
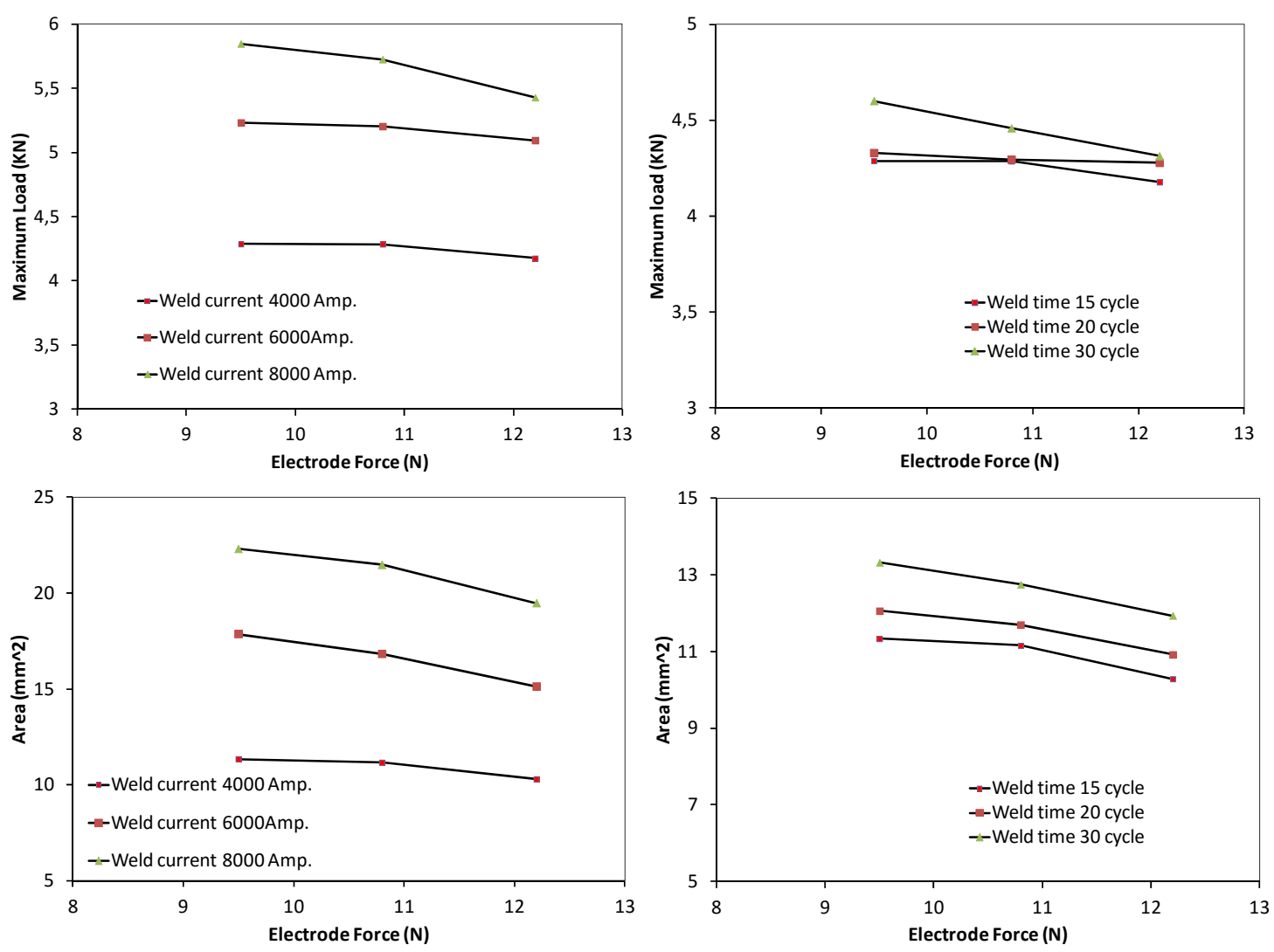

Figure 4. Effect of electrode force on the tensile shear strength and weld nugget area

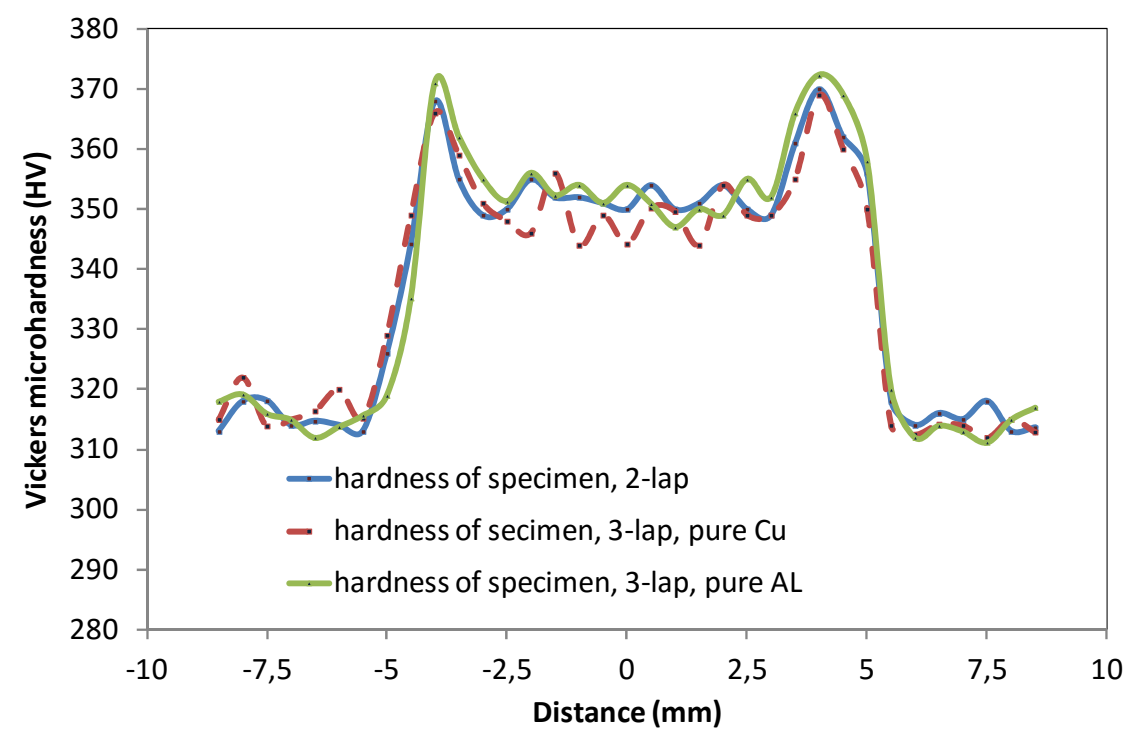

Figure 5. Vickers microhardness profile for spot weld, $\mathrm{I}=6000 \mathrm{Amp}$, time $=30$ cycles, and electrode force $=9.5 \mathrm{~N}$, longitudinal direction 


\subsection{Mechanical and Metallurgical Properties Due to Transition Material}

The use of pure copper as a transition metal between two sheets of austenitic stainless steel 304L reduce the joint strength. The maximum load of joint strength under the conditions (welding current of $8000 \mathrm{Amp}$, welding time of 30 cycles and electrode force of $9.5 \mathrm{~N}$ ) was $6.775 \mathrm{KN}$. The maximum load of joint strength of using transition pure copper was $5.149 \mathrm{KN}$. However, welding under the same condition with the pure aluminum the expulsion occurs in the weld nugget due to the high thermal conductivity. The maximum load of joint strength under the conditions (welding current of $6000 \mathrm{Amp}$, welding time of 30 cycles and electrode force of $9.5 \mathrm{~N}$ ) was $5.743 \mathrm{KN}$, and the maximum load of joint strength of using transition pure copper was $4.5 \mathrm{KN}$; while the maximum load of joint strength of using transition pure $\mathrm{AL}$ was $4.13 \mathrm{KN}$. In other words, the percentage of maximum load decreasing was approximately $24 \%$, and $26 \%$, see Figure 6 . This reduction in maximum load value is due to many reasons; one of the most important of these reasons is the difference in the metals solidification rate and melting temperature change, which leads to shrinkage and cracking. These cracks are in different directions, locations and lengths. However, the intical crack length was determined using fracture mechanic tools, see (A. M. Al-Mukhtar, Biermann, Hübner, \& Henkel, 2010). If the cracks perpendicular to the direction of applied load in the tensile shear test, the maximum load will be low. In the austenitic stainless steel, the austenitic matrix shows relatively low alloying element diffusion rates, a high thermal expansion coefficient and high electric resistance (Hasanbaşoğlu \& Kaçar, 2007).

The fracture stress of spot welding of 2 and 3-lap sheet was investigated by Sin et al. (2007). It was shown that the fracture stress was decreased by inserting a middle sheet due to the decrease in weld ability according to the increase in welding thickness. However, the effect of the multiple interfaced nugget, and the microstructural cracking effect play a significant role in the current work.

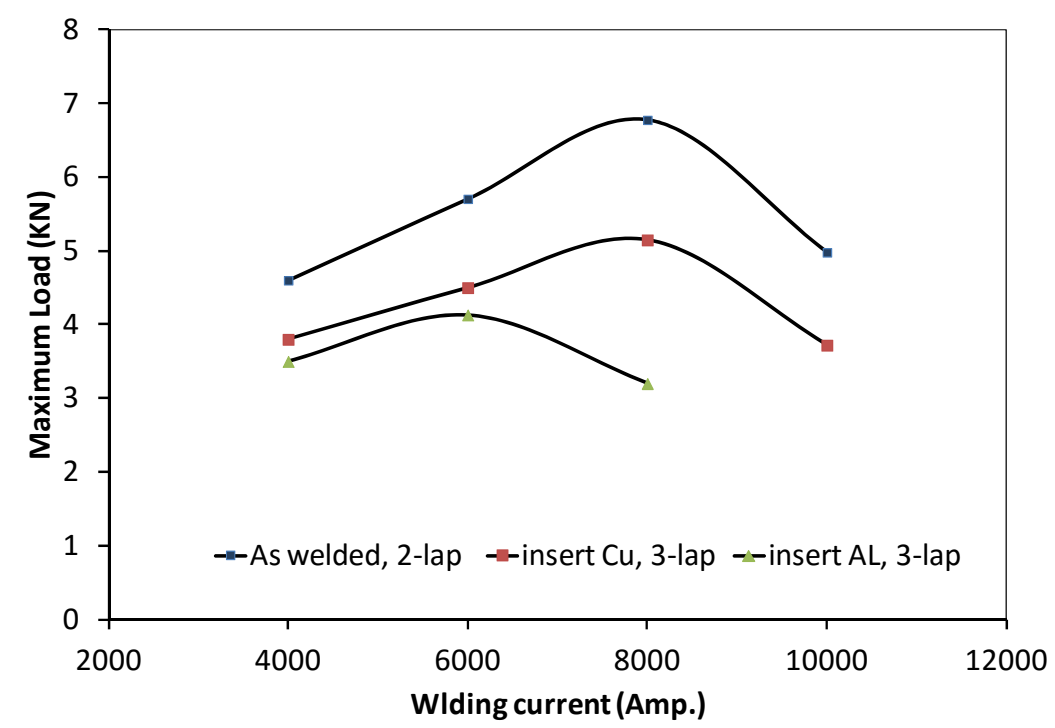

Figure 6. Weld joint strength of 2-lap and 3-lap specimens. Electrode pressure=0.483 MPa, Time $=30$ Cycle

High conductivity materials require more current than mild steels to give an equivalent heat input for two reasons, first, due to the high electrical conductivity and secondly, due to the high conduction of heat away from the weld area. Therefore, the investigation of intermediate metals such copper and aluminum has been introduced. In practice, high conductivity materials such as aluminum are welded for short times with exceptionally high currents (Brandes \& Brook, 1992). The aim of adding the intermediate sheet or the presence of the intermediate layers of different alloys with different electrical and thermal conductivities, is to investigate the substantially heat inputs. Therefore, and however the using of lower current values, a plug fracture was obtained for the 3-lap, see Figure 7. The pressure has to be considered during the welding and precautions to prevent the cracking and cavitations have to be taken. Hence, a lower strength was obtained from the tensile test. 


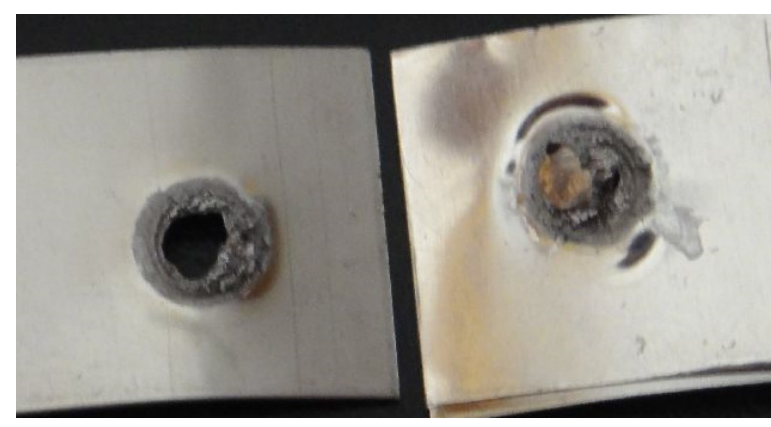

a)

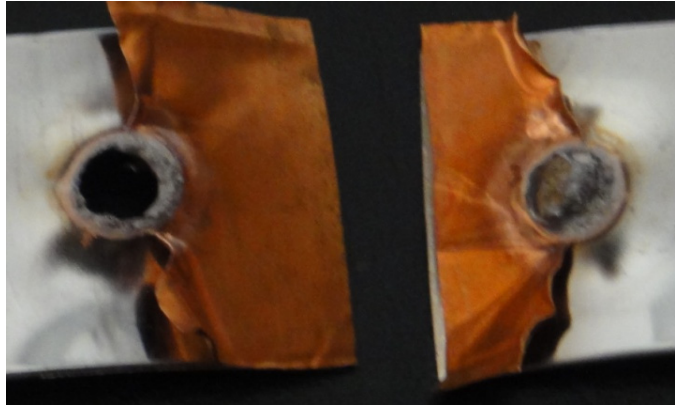

b)

Figure 7. Fracture plug of 3-lap sheets spot welded metal, a) almuimin- stainless steel fracture, b) cupper stainless steel fracture

\section{Conclusions}

In this study the microstructural and mechanical behavior of resistance spot welds done on stainless steel 2-lap and 3-lap sheets, welded at different welding parameters, is carried out. The properties are the most importance which influence weldability is examined. Therefore the suitable welding conditions have been investigated. In this study, two plates of stainless steel were placed as a lap joint (2-lap), and spot welded using varied welding current. In addition, 3-lap specimens were welded. The results show that the increasing welding current increased the nugget size for the 2-lap specimens up to expulsion limit. The nugget has a maximum area before the expulsion. Thus, the strength increases when the nugget diameter is increased. The electrode force decreasing the interface resistance and decreasing the heating and the nugget area. Hence, the maximum carrying load was decreased. In case of 3-lap, the microstructural investigation revealed that the excessive cracking and the intensive melting occurs before the expulsion limit in case of 2-lap. Hence a lower strength was observed. The high thermal conductivity of inserting metals increases the burning and the melting. Thus, the electrode indentation increases. Therefore, a plug fracture was obtained. Using transition pure copper and aluminum reduces the maximum load and microhardness values under the same conditions compare with as- welded specimen.

Microhardness of weld zones increase when insert thin pure aluminum sheet between two austenitic stainless steel sheets due to formation solid compounds such as oxide aluminium.

\section{Acknowledgments}

The authors would like to thankfully appreciate the support received from Dr.-Ing. Ahmed Al-Mukhtar, Guest Scientist at Technische Universität Bergakademie Freiberg, Faculty of Geosciences and Geoengineering and staff member in Al-Khawarizmi College of Engineering, Baghdad University for his fruitful discussions and guidance.

\section{References}

Agashe, S., \& Zhang, H. (2003). Selection of schedules based on heat balance in resistance spot welding. Welding Journal, 1(2), 179-183. Retrieved from http:/www.aws.org/wj/supplement/07-2003-AGASHE-s.pdf

Al-Mukhtar, A., \& Doos, Q. (2013). Cracking Phenomenon in Spot Welded Joints of Austenitic Stainless Steel. Materials Sciences and Applications, 2013(October), 656-662. Retrieved from http://www.scirp.org/journal/ PaperInformation.aspx?paperID $=38635 \&$

Al-Mukhtar, A. M. (2002). Spot Welding Efficiency and its Effect on Structural Strength of Gas Generator and its Performance. Baghdad University.

Al-Mukhtar, A. M. (2003). Investigation of Some Welding Parameters in Resistance Spot Welding of Austenitic Stainless. In 5th Sc. Conference of the College of Engineering, Baghdad University.

Al-Mukhtar, A. M., Biermann, H., Hübner, P., \& Henkel, S. (2010). Determination of Some Parameters for Fatigue Life in Welded Joints Using Fracture Mechanics Method. Journal of Materials Engineering and Performance, 19(9), 1225-1234. http://dx.doi.org/10.1007/s11665-010-9621-5

Al-Mukhtar, A. M., \& Doos, Q. (2013). The Spot Weldability of Carbon Steel Sheet. Advances in Materials Science and Engineering, 2013, 1-6. http://dx.doi.org/10.1155/2013/146896 
Ambroziak, A., \& Korzeniowski, M. (2010). Using Resistance Spot Welding for Joining Aluminium Elements in Automotive Industry. Archives of Civil and Mechanical Engineering, 10(1), 5-13. http://dx.doi.org/10.1016/ S1644-9665(12)60126-5

Aslanlar, S. (2006). The effect of nucleus size on mechanical properties in electrical resistance spot welding of sheets used in automotive industry. Materials and Design, 27(2), 125-131. http://dx.doi.org/10.1016/j. matdes.2004.09.025

Aslanlar, S., Ogur, A., Ozsarac, U., Ilhan, E., \& Demir, Z. (2007). Effect of welding current on mechanical properties of galvanized chromided steel sheets in electrical resistance spot welding. Materials \& Design, 28(1), 2-7. http://dx.doi.org/10.1016/j.matdes.2005.06.022

Brandes, E. A., \& Brook, G. B. B. T.-S. M. R. B. (1992). 33 - Welding. Oxford: Butterworth-Heinemann. http://dx.doi.org/10.1016/B978-0-08-051730-8.50038-8

Connor, L. P. (1987). Welding handbook. Society, 1.

Cullen, J. D., Athi, N., Al-Jader, M. A., Shaw, A., \& Al-Shamma'a, A. I. (2007). Energy reduction for the spot welding process in the automotive industry. Journal of Physics: Conference Series. http://dx.doi.org/10.1088/ $1742-6596 / 76 / 1 / 012022$

Groover, M. P. (2007). Fundamentals of modern manufacturing: materials processes, and systems. John Wiley \& Sons.

Han, L., Thornton, M., Boomer, D., \& Shergold, M. (2010). Effect of aluminium sheet surface conditions on feasibility and quality of resistance spot welding. Journal of Materials Processing Technology, 210(8), 1076-1082. http://dx.doi.org/10.1016/j.jmatprotec.2010.02.019

Hasanbaşoğlu, A., \& Kaçar, R. (2007). Resistance spot weldability of dissimilar materials (AISI 316L-DIN EN 10130-99 steels). Materials \& Design, 28(6), 1794-1800. http://dx.doi.org/10.1016/j.matdes.2006.05.013

Kahraman, N. (2007). The influence of welding parameters on the joint strength of resistance spot-welded titanium sheets. Materials \& Design, 28(2), 420-427. http://dx.doi.org/10.1016/j.matdes.2005.09.010

Kim, T., Lee, Y. S., Lee, J., \& Rhee, S. H. (2004). A Study of Nondestructive Weld Quality Inspection and Estimation during Resistance Spot Welding. Key Engineering Materials, 270-273, 2338-2344. Retrieved from http://www.scientific.net/KEM.270-273.2338

M. Vural, A. A. (2004). the resistance spot weldability of galvanized interstitial free steel sheets with austenitic stainless steel sheets. J Mater Process Technol, 1-6.

Marashi, P., Pouranvari, M., Amirabdollahian, S., Abedi, A., \& Goodarzi, M. (2008). Microstructure and failure behavior of dissimilar resistance spot welds between low carbon galvanized and austenitic stainless steels. Materials Science and Engineering: A, 480(1-2), 175-180. http://dx.doi.org/10.1016/j.msea.2007.07.007

MatWeb. (n.d.). Your Source for Materials Information. Retrieved from http://www.matweb.com/Page1/1.(n.d.),1

Mirsalehi, S. E., \& Kokabi, a. H. (2010). Fatigue life estimation of spot welds using a crack propagation-based method with consideration of residual stresses effect. Materials Science and Engineering: A, 527(23), 6359-6363. http://dx.doi.org/10.1016/j.msea.2010.06.070

Moshayedi, H., \& Sattari-Far, I. (2012). Numerical and experimental study of nugget size growth in resistance spot welding of austenitic stainless steels. Journal of Materials Processing Technology, 212(2), 347-354. http://dx.doi.org/10.1016/j.jmatprotec.2011.09.004

Mukhopadhyay, G., Bhattacharya, S., \& Ray, K. K. (2009). Strength assessment of spot-welded sheets of interstitial free steels. Journal of Materials Processing Technology, 209(4), 1995-2007. http://dx.doi.org/10. 1016/j.jmatprotec.2008.04.065

N R Anand1, V. M. C. * and N. K. S. (2013). The effect of shielding gases on mechanical properties and microstructure of austenitic stainless. International Journal Of Mechanical Engineering And Robotics Research, 2.

Nodeh, I. R., Serajzadeh, S., \& Kokabi, a. H. (2008). Simulation of welding residual stresses in resistance spot welding, FE modeling and X-ray verification. Journal of Materials Processing Technology, 205(1-3), 60-69. http://dx.doi.org/10.1016/j.jmatprotec.2007.11.104 
Park, S. H. C., Sato, Y. S., Kokawa, H., Okamoto, K., Hirano, S., \& Inagaki, M. (2004). Corrosion resistance of friction stir welded 304 stainless steel. Scripta Materialia, 51(2), 101-105. http://dx.doi.org/10.1016/j. scriptamat.2004.04.001

Pereira, a. M., Ferreira, J. M., Loureiro, a., Costa, J. D. M., \& Bártolo, P. J. (2010). Effect of process parameters on the strength of resistance spot welds in 6082-T6 aluminium alloy. Materials \& Design, 31(5), 2454-2463. http://dx.doi.org/10.1016/j.matdes.2009.11.052

Pouranvari, M., Abedi, A., Marashi, P., \& Goodarzi, M. (2008). Effect of expulsion on peak load and energy absorption of low carbon steel resistance spot welds. Science and Technology of Welding and Joining. http://dx.doi.org/10.1179/174329307X249342

Shamsul, J. B., Hisyam, M. M., \& Muhibbah, T. (2007). Study Of Spot Welding Of Austenitic Stainless Steel Type 304. Journal of Applied Sciences, 3(11), 1494-1499.

Sin, S. R., Yang, S. M., Yu, H. S., Kim, C. W., \& Kang, H. Y. (2007). Fatigue Analysis of Multi-Lap Spot Welding of High Strength Steel by Quasi Static Tensile- Shear Test. Key Engineering Materials, 345-346, 251-254. http://dx.doi.org/10.4028/www.scientific.net/KEM.345-346.251

Triyono, T., Purwaningrum, Y., \& Chamid, I. (2013). Critical Nugget Diameter of Resistance Spot Welded Stiffened Thin Plate Structure. Modern Applied Science, 7(7), 17-22. http://dx.doi.org/10.5539/mas.v7n7p17

Tsai, C. L., Jammal, O. a, Papritan, J. C., \& Dickinson, D. W. (1992). Modeling of Resistance Spot Weld Nugget Growth, 71(2), 47s-54s.

Vural, M., Akkuş, a., \& Eryürek, B. (2006). Effect of welding nugget diameter on the fatigue strength of the resistance spot welded joints of different steel sheets. Journal of Materials Processing Technology, 176(1-3), 127-132. http://dx.doi.org/10.1016/j.jmatprotec.2006.02.026

Wei, P. S., \& Wu, T. H. (2012). Electrical contact resistance effect on resistance spot welding. International Journal of Heat and Mass Transfer, 55(11-12), 3316-3324. http://dx.doi.org/10.1016/j.ijheatmasstransfer. 2012.01.040

Welding, R. S., Industry, A., \& Practice, G. (2002). Joining - Resistance welding 2 Resistance welding, 1-19.

Zhang, H., \& Senkara, J. (2006). Resistance Welding Fundamentals and Applications.

Zhou, M., Hu, S., \& Zhang, H. (1999). Critical specimen sizes for tensile-shear testing of steel sheets. Welding Journal-New York-. Retrieved from http://aws.org/wj/supplement/sept99/ZHOU.pdf

\section{Copyrights}

Copyright for this article is retained by the author(s), with first publication rights granted to the journal.

This is an open-access article distributed under the terms and conditions of the Creative Commons Attribution license (http://creativecommons.org/licenses/by/3.0/). 